\title{
Article \\ Gender-Stratified Analysis of Haitian Perceptions Related to Sexual Abuse and Exploitation Perpetrated by UN Peacekeepers during MINUSTAH
}

\author{
Luissa Vahedi ${ }^{1, *}$, , Heather Stuart ${ }^{1}$, Stéphanie Etienne ${ }^{2}$, Sabine Lee ${ }^{3}$ and Susan A. Bartels ${ }^{1,4} \mathbb{1}$ \\ 1 Department of Public Health Sciences, Queen's University, Kingston, ON K7L 3N6, Canada; \\ heather.stuart@queensu.ca (H.S.); susanabartels@gmail.com (S.A.B.) \\ 2 Komisyon Fanm Viktim pou Viktim (KOFAVIV), Port au Prince, Haiti; estephie2011@yahoo.fr \\ 3 Department of History, University of Birmingham, Birmingham B15 2TT, UK; s.lee@bham.ac.uk \\ 4 Department of Emergency Medicine, Queen's University, Kingston, ON K7L 4V7, Canada \\ * Correspondence: 16LV6@queensu.ca
}

Citation: Vahedi, L.; Stuart, H.; Etienne, S.; Lee, S.; Bartels, S.A. Gender-Stratified Analysis of Haitian Perceptions Related to Sexual Abuse and Exploitation Perpetrated by UN Peacekeepers during MINUSTAH. Sexes 2021, 2, 216-243. https: / / doi.org/10.3390/sexes2020019

Academic Editor: Joana Carvalho

Received: 22 April 2021

Accepted: 9 June 2021

Published: 15 June 2021

Publisher's Note: MDPI stays neutral with regard to jurisdictional claims in published maps and institutional affiliations.

Copyright: (c) 2021 by the authors. Licensee MDPI, Basel, Switzerland. This article is an open access article distributed under the terms and conditions of the Creative Commons Attribution (CC BY) license (https:/ / creativecommons.org/licenses/by/ $4.0 /)$.

\begin{abstract}
Feminist scholarship has analyzed the gendered dynamics of national- and internationallevel risk factors for peacekeeper-perpetrated sexual exploitation and abuse (SEA); however, the gendered dynamics within the host country have not been adequately considered. Using the United Nations Stabilization Mission in Haiti (MINUSTAH) as a case study, this research analyzes gender differences within community-level perceptions of SEA. Using SenseMaker ${ }^{\circledR}$ as a data collection tool, cross-sectional qualitative and quantitative data were collected by Haitian research assistants over an 8-week period in 2017. Participants first shared a narrative in relation to MINUSTAH and then self-interpreted their narratives by noting their perceptions, attitudes, and beliefs on a variety of questions. The self-coded perceptions were analyzed quantitatively to determine patterns, and this was complemented with a qualitative analysis of the narratives. Women/girls were more likely to perceive the sexual interactions as "relationships" compared to Haitian men/boys. Furthermore, women/girls were more likely to perceive the peacekeeper as "supportive", whereas men/boys conceptualized the peacekeeper as "authoritative". SEA-related policies/programs, such as the UN Trust Fund in Support for Victims of SEA, should engage with local Haitian actors and consider such nuanced and gendered perceptions to maximize community trust and program efficacy.
\end{abstract}

Keywords: Haiti; peacekeeping; MINUSTAH; sexual abuse and exploitation; gender-based analysis

\section{Introduction}

Peacekeeping operations (PKOs) have traditionally focused on buffering interstate conflict by deploying military, police, and civilian peacekeepers from UN member states [1]. However, in recent decades, the nature of conflict has transcended beyond warring nations to state instability and fragility. Consequently, PKOs have been increasingly deployed to neutralize intrastate conflict, involving long-standing and protracted civil wars, anticivilian violence, coups, and organized crime in fragile settings, and regions characterized by weak or collapsed governance [2]. In this sense, when faced with intrastate conflict, PKOs strive to establish "negative peace" — the absence of active conflict or violencefollowed by long-term peacebuilding activities that underlie "positive peace": the longterm and sustainable absence of structural violence, including social injustice [3].

The peacebuilding activities of PKOs deployed to fragile settings, marred by a circular relationship between violence and weak governance, involve military and police contingents that play an active role in civilian protection through humanitarian response and aid, the protection of human rights, and the support of democratic elections [4,5]. The expanding role of PKOs to include peacebuilding activities may alter the dynamics between foreign peacekeepers and members of the host community. This manuscript is an 
empirical steppingstone to exploring nuanced and gender-disaggregated micro-level data on peacekeeping from the perspectives of community members living in fragile settings.

On 30 April 2004, the United Nations Security Council (UNSC) passed Resolution 1542, thereby establishing The United Nations Stabilization Mission in Haiti (MINUSTAH). In addition to the goal of neutralizing the threat of organized crime and civil unrest in Haiti, MINUSTAH was mandated to achieve three broad goals: (i) protect and stabilize human rights, (ii) support the democratic electoral process, and (iii) assist the interim government of Haiti [6]. MINUSTAH officially began in June 2004 and ended in October 2017, making it the longest PKO in Haiti $[7,8]$. MINUSTAH is among the top four PKOs with the highest number of reported sexual exploitation and abuse (SEA) allegations [9].

Similar to PKOs deployed in the Democratic Republic of the Congo, South Sudan, and the Central African Republic, concerns have been raised about sexual exploitation and abuse (SEA) perpetrated by MINUSTAH peacekeepers, including resultant pregnancies and peacekeeper-fathered children. In fact, since 2007, 118 allegations of SEA against MINUSTAH peacekeepers were formally reported to the UN [10]. Previous research has explored risk factors that are positively associated with cases of reported SEA [11-13]. Namely, large mission size, high level of violence during conflict, low GDP per capita, and a previously established economy of transactional sex are known to be positively associated with reported SEA [11-13]; Haiti and MINUSTAH reflect such patterns on account of the mission size, organized crime and civilian violence, extreme poverty, and transactional sex as a pre-existing source of income and social status. Media reports highlighted that MINUSTAH peacekeepers were implicated in sex trafficking, sexual abuse, and the exploitation of children [14-16].

The effectiveness of the UN's policies and programs related to SEA prevention and response depends, in part, on host community acceptance. In other words, the beneficiaries of assistance, including survivors of SEA, do not necessarily behave in accordance with the UN's top-down policies, but rather in accordance with their lived experiences, social context, perceptions, and beliefs, which are, in part, informed by the social, political, and historical context of the host country. A gender-disaggregated and nuanced examination of Haitian perceptions vis-à-vis MINUSTAH, its peacekeepers, and SEA is warranted given the widespread underreporting of SEA and that the delivery of humanitarian assistance/aid may have increased interactions between civilians and peacekeepers, particularly following natural disasters such as the 2010 earthquake in Haiti. The disaggregation of micro-level peacekeeping data by gender and by conducting gender-based analysis can shed light on the gendered norms, perceptions, and attitudes that operate within host countries and mediate interactions with peacekeepers, PKOs, and the UN's SEA response before, during, and after the experience of SEA. This research analyzes gender differences within community-level perceptions of sexual relationships between Haitians and MINUSTAH peacekeepers. Using the perspectives of Haitian community members at large and the victims / survivors of SEA, we aim to nuance the current understanding of civilianpeacekeeper sexual interactions within the Haitian context and offer recommendations that strengthen the UN's existing victim-centered approach and Trust Fund for victims.

\subsection{The UN's Zero-Tolerance Policy}

The UN's "zero-tolerance policy" defines sexual exploitation as "the actual or attempted abuse of a position of vulnerability, differential power, or trust for sexual purposes" and sexual abuse as "actual or threatened physical intrusion of a sexual nature, whether by force or under unequal or coercive conditions" [17] (p. 1). Transactional sex, which is also prohibited, is defined as "the exchange of money, employment, goods, or services for sexual activity between beneficiaries of assistance and peacekeeping personnel" [17] (p. 2). SEA is a category one offence-the most serious category of misconduct perpetrated by peacekeepers during PKOs [18].

It is also widely stated that sexual relationships between UN staff and beneficiaries of assistance are based upon "inherently unequal power dynamics" and are "strongly 
discouraged" [17] (p. 2, Section 3.2(d)). However, "The Head of Department, Office, or Mission may use his or her discretion in applying the standards prescribed in Section 3.2(d), where beneficiaries of assistance are over the age of 18 and the circumstances of the case justify exception" [17] (p. 3). Therefore, UN forces are prohibited from committing SEA and are strongly discouraged but not completely barred from engaging in sexual relations with beneficiaries of assistance who are above the age of majority.

The zero-tolerance policy clearly defines the boundaries of SEA and transactional sex; however, such definitions are not necessarily reflective of the lived experiences of women and girls who have engaged sexually with peacekeepers or context-specific perceptions of sexual interactions with peacekeepers [19-21]. Critical scholarship with respect to the zero-tolerance policy has highlighted that the broad labeling of abuse and exploitation, applied to all sexual relations, is problematic. For example, the blanket categorization of SEA obscures variability in lived experiences with respect to consensual sexual encounters, fails to address the gendered consequences inherent within the sociopolitical context of fragile settings, and renders invisible cases that cannot be substantiated as SEA, particularly with respect to the conception of peacekeeper-fathered children and obtaining material assistance [22-26].

\subsection{Haitian Context Regarding Sexual and Romantic Relationships}

Sexual interactions with peacekeepers, whether they be SEA, long-term, or consensual, do not occur in a vacuum. Considering Haitian norms pertaining to romantic relationships, the sociopolitical context, and gender can deepen the understanding of how sexual relations with peacekeepers operate within or deviate from normative Haitian society. Taking a systems perspective, gender-based violence in Haiti operates within the legacy of brutal French colonial rule, widespread poverty, unstable governance, foreign intervention, and human rights violations [27]. Haiti remains the first and only republic created through slave revolt $[27,28]$. On account of the colossal "independence tax" imposed, foreign encroachment, diplomatic isolation, and political instability shadowed Haiti's 1804 independence and has deeply entrenched and normalized violence and the use of military force within the fiber of everyday life in Haiti $[27,28]$. Gender-based violence perpetrated against women and girls can be conceptualized as a conflict tactic between political rivals and their proxy armed groups in Haiti [27]. For example, gang rapes were tactics of political repression employed in the 1990s by parties plotting to overthrow the government [27]. The mid-1990s also coincided with the deployment of subsequent PKOs in Haiti, eventually leading to MINUSTAH [29].

In addition to being a tactic of conflict, gender-based violence can also manifest interpersonally within intimate relationships. Legal marriages or unions are common only among a minority of Haitian couples and are associated with higher socioeconomic status and prestige [30]. Within the context of legal marriages in Haiti, no laws against intimate partner violence exist; the prevailing view is that domestic violence is a private matter $[30,31]$. While the age of sexual consent is 18 , date rape has not been legally defined under Haitian law [32]. Outside of legal marriage, sexual violence can be punished under general assault or battery charges [27].

Regardless of legal status, sexual relationships in Haiti run along the lines of heteronormativity and patriarchy. For instance, it is common for Haitian men to practice polygamy by maintaining multiple common-law relationships simultaneously. In addition, compared to Haitian women, Haitian men engage in more casual sexual relationships and are more sexually knowledgeable [33]. Haitian women, on the other hand, are the pillars of Haitian society [33] and are expected to care for domestic life [34]. This gendered division of labor is coupled with limited opportunities for upward socioeconomic mobility, which incentivizes Haitian females to seek out men who are employed and skilled [34,35].

Under such circumstances, women and girls' potential for upward social mobility through romantic partnerships legitimizes patriarchal gender relations [27]. Examples of patriarchal norms operating within sexual relationships in Haiti include the normalization 
of sexual violence in relationships, subjugation of female desires, and implied sexual consent within a sexual relationship or dating context [27,34]. Given that Haitian women and girls depend financially on men, sexual activity is commodified, thereby eroding female sexual rights and freedoms, such as engaging in consensual safe sex [27,34].

Women and girls are expected to engage in sexual activity by virtue of accepting a dating invitation [27,34]. Consequently, the sexuality of young girls is often kept under the watchful gaze of family members and caregivers, who may encourage or discourage dating depending on socioeconomic status. Families facing precarious socioeconomic conditions may encourage dating and transactional sex as a means of alleviating poverty $[27,34]$. The influx of peacekeepers, who are predominantly male, foreign, and well paid in relation to the Haitian economy, occurs within the context of existing structural gender inequality and gender-based violence in Haiti. Thus, transactional sex and SEA perpetrated by peacekeepers must be situated within the Haitian context.

\subsection{Criminal Immunity}

The UN does not have a contingent of permanent peacekeeping personnel; instead, troops are assembled ad hoc from member states [36]. The relationship between the UN, troop- and police-contributing countries (TPCCs), and host countries is regulated in Status-of-Forces Agreements (SOFAs). The SOFAs, among others, determine that military members of national contingents are given immunity from host-state jurisdiction for criminal acts that are undertaken during their official capacity [37]. Disciplinary authority is the responsibility of the TPCCs, as outlined by the Memorandum of Understanding between TPCCs and the UN $[36,38,39]$.

Essentially, the UN grants criminal immunity from host-state prosecution to military peacekeeping personnel because the TPCCs are responsible for prosecution. Criminal immunity is intended to support peacekeeping personnel in fulfilling mission objectives without intrusion from the host state. However, member states are not legally obligated to undertake the criminal prosecution of peacekeepers. In fact, it is common for member states to fall short of implementing the Memorandum of Understanding, leading to criminal immunity in the host country without prosecution in the TPCC [40].

\subsection{Peacekeeper-Fathered Children (Peace Babies)}

In 2007, the UN adopted Resolution 62/214: "The Comprehensive Strategy on Assistance and Support to Victims of Sexual Exploitation and Abuse by United Nations Personnel and Related Personnel". This resolution was the UN's first acknowledgment of children "who are found by a competent national authority to have been born as a result of acts of SEA by UN staff or related personnel" [41] (p. 3). Under Resolution 62/214, the UN outlines its roles and responsibilities with respect to SEA and children fathered by peacekeepers. The financial and legal role of the UN is that of a liaison between TPCCs and the host country. In other words, the UN maintains its commitment to supporting victims of SEA but bears no legal liability for committed acts of SEA [26].

\subsection{UN's Institutional Response to SEA}

A series of UN institutional reforms followed the 2003 "zero-tolerance policy". The UN's first formal response and systematic investigation of SEA perpetrated by peacekeepers was in the 2005 Comprehensive Strategy to Eliminate Future Exploitation and Abuse in United Nations Peacekeeping Operations, also known as the Zeid Report [42]. The Zeid Report made a number of recommendations with respect to preventing and responding to SEA, including the first mention of establishing a Trust Fund for victims to receive assistance, in addition to acknowledging that data on SEA cases does not reflect the true extent of such crimes, and recognizing the trauma, stigmatization, and exploitation faced by victims. The report also stated that reporting is inhibited by "cases involving prostitution where there is no economic incentive to report", drawing attention to the social, economic, and political context of the host country: eroded social fabric, extreme poverty, lack of income generation, gender discrimination, and 
impunity [42] (p. 10). The UN has implemented a number of recommendations from the Zeid Report; however, the overarching theme of its SEA policy is reactive in that it addresses the symptoms and consequences of SEA rather than the fundamental causes of gender inequality, impunity, and host-state fragility.

For example, in 2005, the UN established Conduct and Discipline Units (CDUs) within PKOs to address misconduct perpetrated by peacekeepers and ensure compliance with UN codes of conduct through training [43]. The mandate of the Office of Internal Oversight Services, originally established in 1994, was also expanded to include auditing, investigation, inspection, and evaluation of SEA allegations [43]. The UN disciplines peacekeepers who are found to be in violation of the zero-tolerance policy through dismissal from service, repatriation, and barring from future service. In cases of SEA, the UN may suspend the peacekeeper's payments and transfer them to the UN Trust Fund in Support for Victims of SEA [17,42,44,45].

In 2017, the UN expanded its commitment with respect to responding, mitigating, and preventing SEA by adopting a novel victim-centered approach to preventing and responding to SEA [46]. The position of Victims' Rights Advocate (VRA) was established in 2017 with the appointment of Ms. Jane Connors [46]. In addition, a Field Victim's Rights Advocate (FVRA) has been designated in Haiti, among other host countries, including the Central African Republic, the Democratic Republic of the Congo, and South Sudan, due to the high magnitude of SEA allegations [9]. Together, the VRA and FVRAs work across the UN's system, field, and headquarters to identify and protect victims of SEA and promote and protect the rights of victims by ensuring they receive comprehensive, rapid, sensitive, and multifaceted support [9]. In addition, both the VRA and FVRAs are involved with overseeing the UN Trust Fund in Support for Victims of SEA, established in 2016, to support the delivery and financing of services and projects for victims/survivors [9].

Given that the Trust Fund has only completed one implementation cycle and that projects in Haiti are in the pipeline [9], the current research is of relevance to the Trust Fund's ongoing and future design, implementation, and evaluation of programs for victims/survivors and other vulnerable groups. The success and use of Trust Fund programs are dependent on community-level acceptance and confidence in SEA reporting. Gendered perceptions, attitudes, and beliefs of peacekeepers and SEA may mediate the relevance and perceived effectiveness of Trust Fund programs and SEA reporting mechanisms, which, in turn, may affect levels of participation and program sustainability. The current research highlights empirical results that may improve the UN's current victim-centered approach by critically considering the nuanced contextual and gendered perceptions of PKOs, peacekeepers, and SEA among Haitians living in proximity to MINUSTAH.

\subsection{Gender Norms}

Given that the present research seeks to explore gender differences with respect to perceptions of SEA, it is important to distinguish biological sex from gender. Biological sexual dimorphism is differentiated from the social roles, behaviors, and preferences ascribed upon bodies recognized as being male or female. Thus, the framing of gender as separate and distinct from biological sex critically questions the previously uncontested "natural" and "innate" differences between males and females. We conceptualize gender norms according to the Cislaghi and Heise [47] (pp. 9-10) definition:

Social norms defining acceptable and appropriate actions for women and men in a given group or society. They are embedded in formal and informal institutions, nested in the mind, and produced and reproduced through social interaction. They play a role in shaping women's and men's (often unequal) access to resources and freedoms, thus affecting their voice, power and sense of self.

\subsection{Gender and Peacekeeping Operations}

The UN has adopted a number of resolutions concerning Women, Peace, and Security since 2000. The Women, Peace, and Security agenda recognizes the centrality of women 
in conflict prevention and accordingly calls on increasing women's participation in peace processes, implementing peace agreements, and decision making [48]. Specifically, since the adoption of United Nations Security Council Resolution (UNSCR) 1325, discourses pertaining to peacekeeping and peacebuilding have integrated gender. UNSCR 1325 recognized that armed conflict has a disproportionate impact on women and girls [49]. A rich body of scholarship adopting a feminist perspective to conflict has emerged since the adoption of UNSCR 1325. Of interest, particularly to peacekeeping and peacebuilding, much of this scholarship integrates feminist analysis at the macro-level by examining the gendered geopolitical and economic contexts of PKOs and the gendered division of UN peacekeepers.

For example, feminist scholarship has enriched the intersectional understanding of military masculinity by considering the geopolitical positions of TPCCs [50]. Briefly, militarized masculinities differ according to the composition of TPCCs; the "masculine" traits of dominance, associated with aggression and violence, are mirrored and perpetuated unequally between male troops from the global north versus the global south [50,51]. Through military masculinity, Higate [51] explored the gendered dimensions of peacekeeper-perpetrated SEA. The social practices of male peacekeepers toward local women and girls flow from their military-masculine identities, positioned in opposition to the feminine "other". Moreover, in terms of troop composition, feminist scholarship has also examined the gender composition of peacekeepers to conclude that while women's participation in PKOs has increased, women still make up an insignificant minority of peacekeepers and are subjected to forced protection from the dangers of conflict when deployed, which makes them unable to challenge patriarchal structures [52-54]. Lastly, scholars have studied peacekeeping economies. Accordingly, the influx of predominantly male peacekeepers within host countries increases the demand for "women's labor" (i.e., waitressing, sex work, domestic work), thereby magnifying the gendered division of labor in the host countries [55].

While such analyses have expanded the peacekeeping discourse to include a gender perspective, gendered dynamics are analyzed almost exclusively in relation to the composition of troops and their social norms while on duty. Feminist scholarship focused on peacekeeping and peacebuilding has paid close attention to the specifics of national and international contexts, with less attention given to the local contexts of the host country at the micro-level. Thus, a critical examination of how gender dynamics within the host country shape the perspectives, norms, and behaviors of civilians in relation to interactions with peacekeepers and the PKO is lacking. Similar to other social identities such as race, age, or class, gender is a strong differentiator between people; arguably, no other salient characteristic of appearance or behavior is as primary to everyday life as gender [47]. The question that remains is, what gender differences, if any, exist in how civilians in host countries interact with and perceive peacekeepers and PKOs? We make an attempt at addressing this question by conducting a secondary exploratory data analysis using empirical data collected by our research team in Haiti.

\subsection{Purpose}

The purpose of the present research is to undertake an exploratory and secondary analysis of gender differences among Haitian perceptions of SEA involving MINUSTAH peacekeepers and women/girls in Haiti. Qualitative narratives from Haitian men and women are presented in order to contextualize the emerging quantitative findings.

\section{Materials and Methods}

\subsection{Study Design}

Between June and August of 2017, Haitian research assistants administered a crosssectional survey that collected both quantitative and qualitative data (Appendix A). Data were collected from persons who were at least 11 years of age and lived in proximity to MINUSTAH peacekeeping bases. The minimum age for participation was 11 years old in order to capture 
the wide range of experiences with peacekeepers, including SEA perpetrated against children. The survey did not ask participants to share experiences of SEA, nor did it mention sexual relations with peacekeepers. Research assistants administered the cross-sectional survey using the SenseMaker ${ }^{\circledR}$ application on iPad tablets.

In total, there were 12 Haitian research assistants from 2 community partner organizations: Komisyon Fanm Viktim pou Viktim (KOFAVIV) and Enstiti Travay Sosyal ak Syans Sosyal (ETS). Research assistant training occurred over four days and covered study introduction, research protocol, SenseMaker, research ethics, iPad use, data upload, management of adverse events, service referral, and role-play practice for survey delivery. The current analysis is derived from a larger cross-sectional study that examined interactions between UN personnel in Haiti and local women/girls [21].

\subsection{SenseMaker}

SenseMaker is an efficient mixed-methods data collection software and research tool developed by Cognitive Edge [56]. SenseMaker's narrative-based approach involves the collection of short narratives related to a defined phenomenon (in this case, interactions between Haitian women/girls and MINUSTAH peacekeepers) and asks participants to convey the meaning of their narrative by responding to a series of questions that are quantitatively coded. Collectively, the participants' self-interpreted narratives create a nuanced picture of the phenomenon in the same way pixels come together to produce a clear image [57]. To elicit participant narratives, we used three prompting questions pertaining to the experiences of women and girls with MINUSTAH peacekeepers. However, none of the prompts explicitly mentioned sexual interactions.

After selecting one prompt and sharing a narrative, participants were asked to selfinterpret the described experiences by plotting their perspectives spatially between three possible options (termed triads). The original cross-sectional survey consisted of eight triad questions. SenseMaker assigns quantitative values to the self-interpretations, allowing for the computation of descriptive statistics. Triad questions ask participants to consider three perceptions/feelings/beliefs related to the narrative shared. Participants plot their perceptions within an equilateral triangle (triad) labeled by three response options that are all of the same emotional tone (i.e., positive, negative, or neutral).

At the end of the SenseMaker survey, participants answered six multiple-choice questions pertaining to demographic characteristics (e.g., age, gender, education level) and micro-narrative characteristics (e.g., emotional tone, protagonist, frequency of occurrence). Lastly, the research assistants were asked to complete eight multiple-choice questions that identified the a priori phenomenon of interest.

The SenseMaker survey was originally drafted in English by team members from all academic and community partners. The survey questions were translated to Haitian Kreyol and back-translated to English by an independent translator to verify accuracy across cross-cultural settings. Translation discrepancies were resolved by consensus between the translators. The survey was pilot-tested in Haiti among 54 participants who provided feedback that was used to improve clarity, ease of response, participant comfort, and translation inaccuracies prior to implementing the final version of the survey. The shared micro-narratives were audio-recorded and later translated from Haitian Kreyol to English for qualitative analysis.

The research team purposefully selected MINUSTAH bases using a combination of key informant knowledge from the community partners, publicly available peacekeeping data, and data pertaining to base staffing characteristics, including the number of military peacekeepers between September 2011 and March 2013, staffing by international contingents between 2005 and 2015, geographical location (north, south, central plateau, metropolitan areas), and dates of operation. The purposeful selection of MINUSTAH bases was intended to ensure adequate inclusion of active peacekeeping bases and comparable levels of civilian-peacekeeper interaction between bases. 


\subsection{Participant Accrual}

Research assistants were instructed to recruit participants from cities, towns, and villages within a $30 \mathrm{~km}$ radius of the purposefully selected MINUSTAH bases. When the $30 \mathrm{~km}$ radiuses for two bases overlapped, the research assistants would alternate between the two bases, and the bases were then grouped into a single location. For example, survey collection was grouped for Charlie Log Base and Tabarre, St. Marc and Gonaives, and Morne Casse and Fort Liberté. In total, the 11 MINUSTAH bases were organized into seven location groups.

Male and female Haitian research assistants recruited a convenience sample of individual participants within each city, town, and village that hosted a MINUSTAH peacekeeping base from naturalistic community settings, including markets, post offices, commercial settings, and bus stops. The research assistants were encouraged to approach potential participants of the same gender. Moreover, we did not collect demographic data from persons who self-selected out of the study, including the number of non-respondents. The cross-sectional survey was conducted in Haitian Kreole using SenseMaker.

\subsection{Data Analysis}

Statistical analysis followed the strategy of a previously published study [58]. SenseMaker data were exported to Tableau version 10.4.0, where participant response patterns were examined visually for each triad. The average response for each stratified sub-group was computed using the geometric mean-the central tendency of participant responses computed using the product of their values [59]. The geometric mean is best conceptualized as a single number that could replace the individual data points while keeping the overall product of the terms unchanged [60].

Geometric means and the surrounding 95\% confidence intervals (illustrated as ellipses), stratified by gender, were the computed summary measures. Geometric means of the stratified groups were computed by the SenseMaker consultant using R scripts in version 3.4 .0 and compared visually for overlap. If the $95 \%$ confidence ellipses surrounding two geometric means did not overlap, the stratified groups were considered to be statistically different. Wider ellipses indicated less precision around the point estimate for the geometric mean, while narrower ellipses indicated more precision.

Decisions pertaining to whether narratives mentioned or addressed sexual misconduct were first made by the Haitian research assistants immediately following data collection. During analysis, the first author then verified the research assistant designation using standardized criteria. Narratives that mentioned or described any sexual interactions with peacekeepers, regardless of the age of the host community member, were identified as being about sexual misconduct. Namely, long-term sexual relationships perceived as consensual, children fathered by peacekeepers, sexual assault, statutory sexual assault, and SEA involving men and boys were all classified as SEA.

\subsection{Contextualizing the Quantitative Results Using Narratives}

The first author reviewed the qualitative narratives to facilitate an in-depth contextualization of the descriptive results. Narratives interpreted by the participants in the direction of the statistically significant differences were read and qualitatively analyzed by the first author in Tableau 10.4.0. For example, when statistically significant triad differences between male and female Haitians were identified, the qualitative narratives corresponding to gendered response patterns were identified by focusing on narratives in the appropriate triad vertices.

All narratives interpreted in the direction of statistically significant response patterns were read and considered for inclusion. However, only narratives comprised of thick descriptions that explained the significant differences between the stratified groups were included. For each triad, one qualitative narrative was included for each of the three stratified groups: the comparator group (narratives that did not address SEA), narratives from female Haitians addressing SEA, and narratives from male Haitians addressing SEA. 
The narratives were also selected for variation across participant demographic factors, such as location and age. The qualitative narratives are meant to contextualize the descriptive patterns noted in the quantitative analysis by leveraging the voices and experiences of the Haitian participants.

\subsection{Ethics}

The University of Birmingham's Ethical Review Board (protocol ERN_16-0950) and Queen's University Health Sciences and Affiliated Teaching Hospitals Research Ethics Board (\#6020398; \#6023714) granted research ethics approval for the cross-sectional survey and the secondary analysis. Trained Haitian research assistants introduced the study to participants in Kreole using a standard script, and informed consent was obtained. Participants indicated their consent by tapping a consent box on the tablet. No compensation was provided. All interviews were conducted confidentially, and the research assistants did not record identifying information. Given that the survey did not ask questions about SEA and participants could share any narrative they wanted, the study was considered to involve minimal risk, and written consent was waived. Adolescents aged 11 and older were included because they were known to be affected by SEA [61], and it would have been unethical to exclude them and their perspectives. Parental consent for the inclusion of minors was not sought since the adolescents were considered mature minors; involving parents would likely have introduced bias and risk for parental conflict and/or abuse if the SEA was unknown to them $[62,63]$. The Haitian research assistants considered Haitian adolescents for inclusion into the study if they were in public, independent of adults or caregivers, and performing adult-like activities such as caring for other younger children. This rationale was used to capture the perspectives of Haitian adolescent females who may themselves be mothers to peacekeeper-fathered children or have experienced peacekeeper-perpetrated SEA. Given that there were no explicit (or implicit) questions about SEA and sexual interactions in the survey, participants were in control of the narratives they provided, and the prompting questions were non-specific; any risk associated with participation was considered low and outweighed by the potential benefits of inclusion in the study.

Team members from KOFAVIV, a grass-roots Haitian organization for sexual violence survivors, were onsite to offer immediate support to participants, and all participants were offered referrals to KOFAVIV and Bureau des Avocates Internationaux (BAI) for legal counsel. To mitigate the risk of psychological distress, the survey intentionally did not ask participants to share experiences of SEA, nor did the questions mention sexual relations with peacekeepers. No identifying information was collected, and participants were requested not to use the names of real people when reciting their experiences. To ensure data security, all completed surveys were uploaded from the tablets to a secure server and then subsequently permanently deleted from the tablets.

\section{Results}

3.1. Sample

In total, 2541 self-interpreted narratives were collected from 2191 unique participants (participants were given the option to share and self-interpret an additional narrative, resulting in a larger number of narratives than unique participants). The unit of observation for the three objectives was the narrative, as opposed to the individual participant.

\subsubsection{Characteristics of the Narrators (Participants)}

Participant demographics are presented in Table 1. Most participants attained some secondary school education or higher, with secondary schools being the most represented level of education (37.9\%). Most participants attained an income that was considered to be "average" $(63.3 \%)$, were male $(69.6 \%)$, below the age of 35 years $(66.1 \%)$, and were single/never married (60.5\%). 
Table 1. Participant demographic characteristics.

\begin{tabular}{|c|c|}
\hline Demographic Characteristic & All Respondents [n (\%)] \\
\hline \multicolumn{2}{|l|}{ Education } \\
\hline No formal education & $118(5.4)$ \\
\hline Some primary school & $269(12.3)$ \\
\hline Completed primary school & $250(11.4)$ \\
\hline Some secondary school & $831(37.9)$ \\
\hline Completed secondary school & $416(19.0)$ \\
\hline Some post-secondary school & $217(9.9)$ \\
\hline Completed post-secondary school & $90(4.1)$ \\
\hline \multicolumn{2}{|l|}{ Income * } \\
\hline Poor & $670(30.6)$ \\
\hline Average & $1386(63.3)$ \\
\hline Well-off & $135(6.2)$ \\
\hline \multicolumn{2}{|l|}{ Gender } \\
\hline Female & $664(30.3)$ \\
\hline Male & $1526(69.6)$ \\
\hline Prefer not to say & $1(0.05)$ \\
\hline \multicolumn{2}{|l|}{ Age } \\
\hline $11-17$ years old & $216(9.9)$ \\
\hline 18-24 years old & $508(23.2)$ \\
\hline 25-34 years old & $724(33.0)$ \\
\hline $35-44$ years old & $360(16.4)$ \\
\hline $45-54$ years old & $206(9.4)$ \\
\hline$>55$ years old & $127(5.8)$ \\
\hline Prefer not to say & $48(2.2)$ \\
\hline Missing & $2(0.09)$ \\
\hline \multicolumn{2}{|l|}{ Location ** } \\
\hline Cap Haitien & $246(11.2)$ \\
\hline Charlie Log Base and Tabarre & $168(7.7)$ \\
\hline Cité Soleil & $341(15.6)$ \\
\hline Hinche & $303(13.8)$ \\
\hline Leogane & $314(14.3)$ \\
\hline Morne Casse and Fort Liberté & $192(8.8)$ \\
\hline Port Salut & $313(14.3)$ \\
\hline Saint Marc and Gonaives & $314(14.3)$ \\
\hline \multicolumn{2}{|l|}{ Marital Status } \\
\hline Divorced/Separated from spouse & $18(0.8)$ \\
\hline Married or living together as if married & $796(36.3)$ \\
\hline Single, never married & $1326(60.5)$ \\
\hline Widowed & $15(0.7)$ \\
\hline Prefer not to say & $36(1.6)$ \\
\hline
\end{tabular}

* Income level of participants: Participants were asked to identify which of the following items were present in their household: (i) radio; (ii) mobile phone; (iii) refrigerator or freezer; (iv) vehicle, such as a truck, car, or motorcycle; (v) generator, inverter, or sun panel that provides electricity to your home; (vi) none of these. The number of items in the household was used as a proxy for participant income levels. Poor: 0-1 items, Average: 2-3 items, Well-off: 4-5 items. ${ }^{* *}$ The sites of data collection within Port-au-Prince are Cité Soleil, Charlie Log Base, and Tabarre. $n=2191$ unique narrators.

\subsubsection{Narrative Characteristics}

Of the 2541 self-interpreted narratives, $682(27 \%)$ addressed or mentioned the phenomenon of sexual interactions between MINUSTAH peacekeepers and Haitian civilians. Most of the stories addressing sexual misconduct perpetrated by peacekeepers were shared by Haitian men $(74 \%)$ compared to Haitian women $(26 \%)$. The greater number of SEA narratives shared by Haitian men compared to Haitian women is also mirrored in non-SEA narratives, with Haitian men contributing 1803 (71\%) narratives.

\subsection{Descriptive Results: Gender Differences}

Analysis of triad data revealed statistical differences when data were stratified by (i) gender and (ii) whether the narratives addressed sexual misconduct perpetrated by 
MINUSTAH peacekeepers. Differences were identified in how Haitian men and women perceived MINUSTAH peacekeepers who perpetrated sexual misconduct and in how to classify the nature of sexual interactions with peacekeepers.

The first presented triad asked participants to consider whether their narrative was about (i) financial/material security, (ii) social status, or (iii) emotional needs. As illustrated in Figure 1, the geometric mean for all respondents was predominantly in the direction of "social status", midway between "financial/material security" and "emotional needs".

\section{This is a story about:}

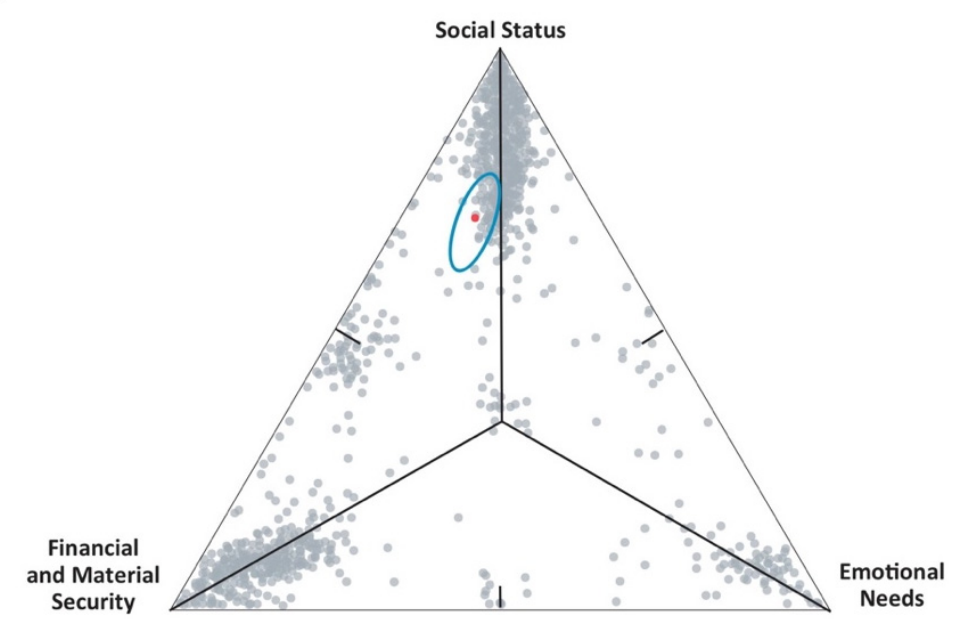

Figure 1. Geometric mean for Triad 1: This Story is about: (i) financial and material security; (ii) social status; (iii) emotional needs.

When the data were disaggregated, narratives addressing sexual misconduct perpetrated by MINUSTAH peacekeepers were statistically different from narratives that did not address sexual misconduct (Figure 2). Participants who did not address sexual misconduct perpetrated by peacekeepers were more likely to respond in the direction of "social status". For example, one male respondent living near Tabarre, who responded in the direction of "social status", explained that MINUSTAH peacekeepers cared for his children:

After the earthquake, I had two kids who were in an accident. I had a friend ... who was on his way to MINUSTAH's office, he was bringing his children to get care at the MINUSTAH's office, the office in Tabarre. I brought my kids there as well. At the time, it was true we received care, people at the MINUSTAH's office provided good care, the kids survived. To this day, the kids are [still] doing very well, they have no issues. (Tabarre, 45-54 years old)

Narratives addressing the phenomenon of sexual misconduct perpetrated by MINUSTAH peacekeepers were less likely to be perceived as being about "social status" and more likely to be perceived in the direction of "financial/material security" and "emotional needs". This finding was consistent among male and female Haitians who addressed sexual misconduct in their narratives; there were no gender differences between male and female respondents. For example, one male participant from Hinche described transactional exchanges between MINUSTAH peacekeepers and female Haitians:

The MINUSTAH caused a lot of chaos, especially with young ladies, because they made promises to the ladies, like they would say that they are going to pay for their school, allow them to go to the university, but nothing has materialized. The MINUSTAH put a lot of divisions between parents and the ladies, even though we knew they were not there for long, but they left a lot of issues in the area. (Hinche, 25-34 years old) 


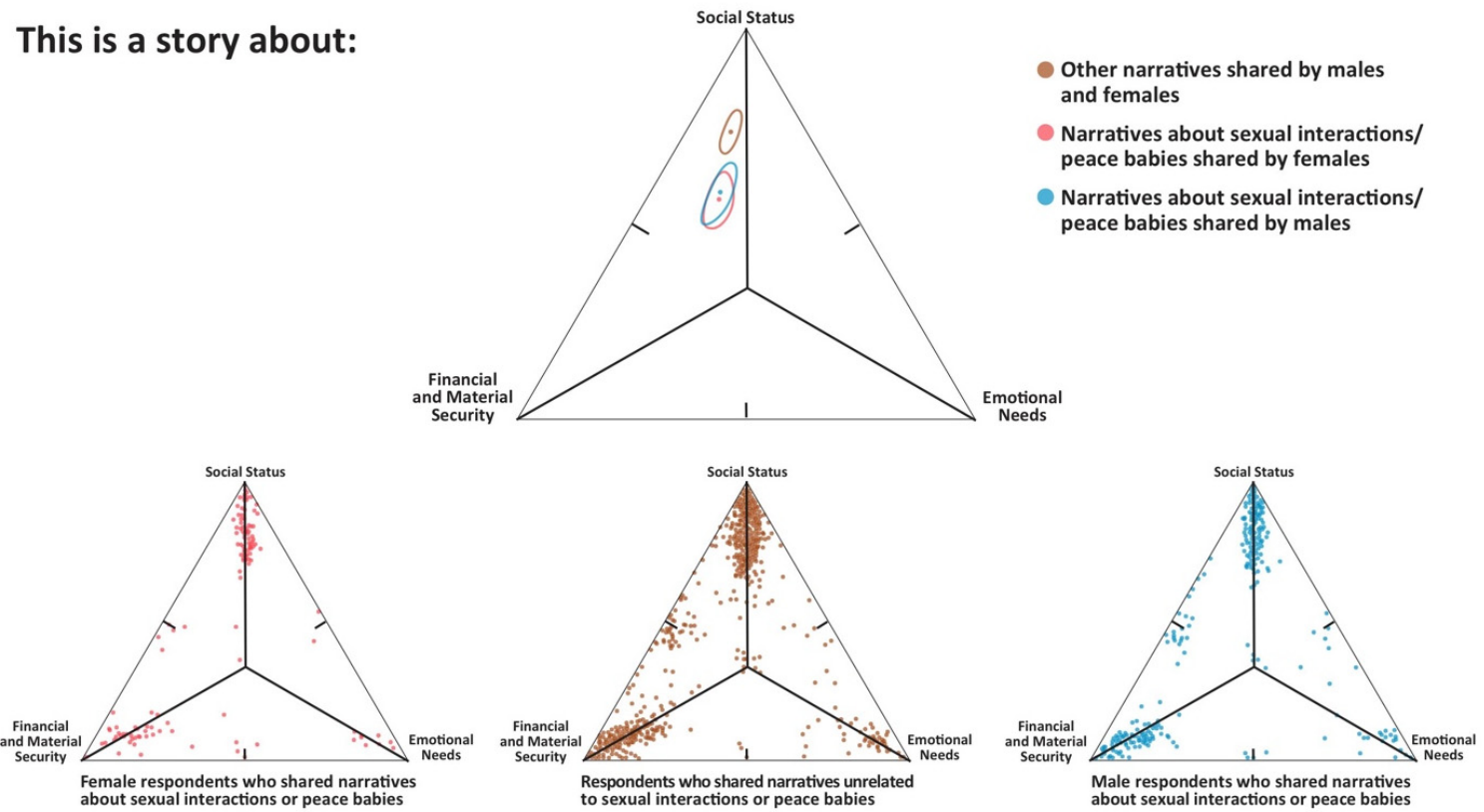

Figure 2. Disaggregated geometric means for Triad 1.

A female respondent from Port Salut shared her personal experiences raising a child fathered by a MINUSTAH peacekeeper:

The MINUSTAH had a base here, they always had time off and time to go to the beach. So, I met with one, we talked, then we became friends, afterwards he came to my home often, then the friendship went further, and after a lot of time we were in love. I was 17 years old and he had a party for me and we started a sexual relationship. So, I became pregnant and then my parents found out. They put him in jail for a month and he went back to his country. When he got there, I used to call him, he sent me money until I gave birth, since then I have not heard from him again. It has been 1 year and 9 months. Now I am caring for the child, send him to school. I am just suffering with him because I have no longer heard from his dad. Although many people tried to reach him, nothing ever happened. (Port Salut, 18-24 years old)

The transactional nature of the sexual interactions and the ongoing need for the peacekeeper to provide child support alongside the peacekeeper's abandonment may explain why narratives addressing SEA were more likely to be interpreted as being about "financial/material security" and "emotional needs".

The second presented triad asked participants to consider whether the foreign UN or MINUSTAH personnel was (i) in a position of authority, (ii) able to offer protection, or (iii) wealthy and able to provide support. As depicted in Figure 3, the overall geometric mean of the responses was located slightly in the direction of "able to offer protection", equally between "in a position of authority" and "wealthy and able to provide support".

For example, one male participant from Hinche who responded at the exact center of the triad had mixed feelings about the role of the UN and MINUSTAH peacekeepers:

MINUSTAH generally helps the national police on election days, when we have elections. Well, when elections do happen. They stop chaotic fights among opposing parties from happening. They brought cholera. Sometimes, it's hard to see how they help the country by bringing in diseases. Other countries provide aid to eradicate cholera in the country. It's not the UN that gives aid toward this disease. Other places, like the US, Cuba, they are the ones who brought aid to combat cholera; in Haiti though, MINUSTAH was the one to bring it in. (Hinche, 18-24 years old) 


\section{In this story, the foreign UN or MINUSTAH personnel was:}

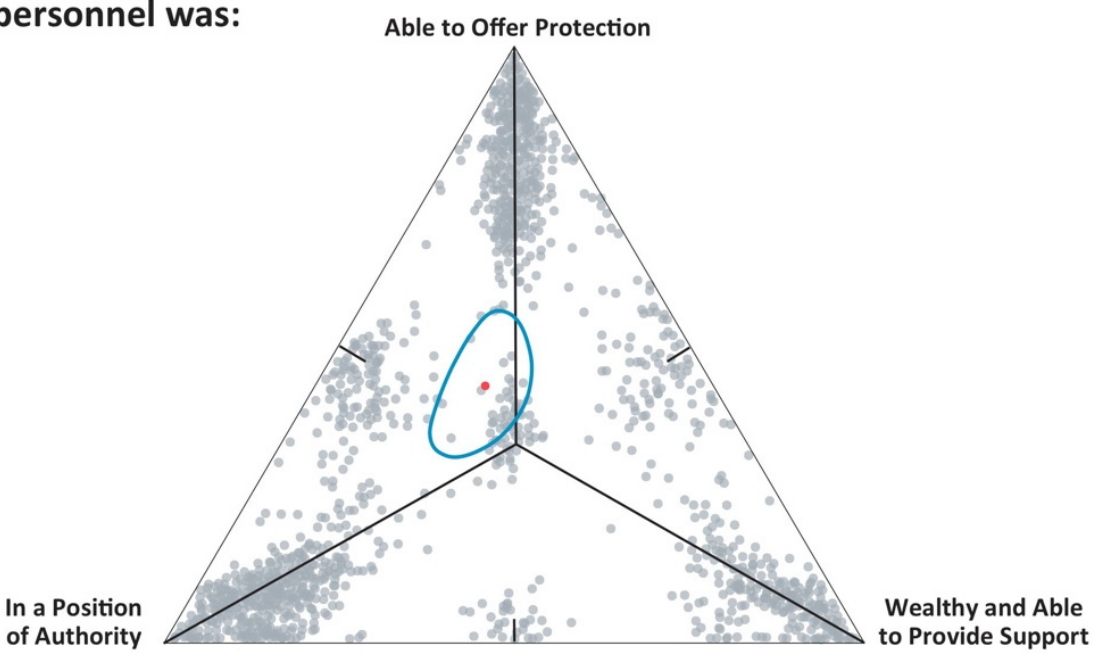

Figure 3. Aggregated geometric mean for Triad 2: In the story, the foreign UN or MINUSTAH personnel was (i) in a position of authority, (ii) able to offer protection, or (iii) wealthy and able to provide support.

When disaggregated by subject matter, narratives addressing sexual misconduct were statistically different from narratives that did not address sexual misconduct. As shown in Figure 4, participants who shared narratives about sexual misconduct were less likely to perceived UN/MINUSTAH personnel as "able to offer support", given the SEA narratives were more likely to be in the direction of the peacekeeper being perceived as "in a position of authority" and "wealthy and able to provide support". Given the small degree of overlap between the $95 \%$ confidence ellipses and wide confidence ellipses surrounding the point estimates for Haitian females and males, this sample may have been underpowered to allow for the complete separation of the confidence ellipses. Accordingly, Haitian women may be more likely to perceive peacekeeping personnel as "wealthy and able to provide support" compared to Haitian men who may be more likely to see the peacekeeping personnel as being "in a position of authority".

Haitian women who perceived the peacekeeper as "wealthy and able to provide support" shared narratives about losing contact with the peacekeeper who fathered their child. For example, one woman from Port Salut shared a first-person account:

I have a child that was fathered by a MINUSTAH member. I spent quite a bit of time with the MINUSTAH [peacekeeper]. He used to come to my house. I became pregnant. We were still together while I was pregnant, up to the time when I gave birth. Then his tour of duty ended, he went back to his country, and ever since, I do not have any information about him. As the child is growing up, I do not hear about him anymore. He does not call me. Now I have to be the one to educate this child, take care of his health and shelter. (Port Salut, 35-44 years old)

Haitian men who perceived peacekeepers as being "in a position of authority" described instances of SEA involving children, alluding to power and privilege imbalances between peacekeepers and Haitian children. For example, one man from Cité Soleil stated:

Well, it hurts me to watch what MINUSTAH are doing in Cité Soleil. They raped many children, and the children are underage. Because of the small portion of food and the money that they gave them, they raped them. Some of them got pregnant; A kid will be the mother to another kid. MINUSTAH are the ones who give a lot of trouble in Cite Soleil. MINUSTAH needs to leave the country because too many kids get impregnated ... I demand justice for women and children who are getting pregnant. (Cité Soleil, 35-44 years old) 


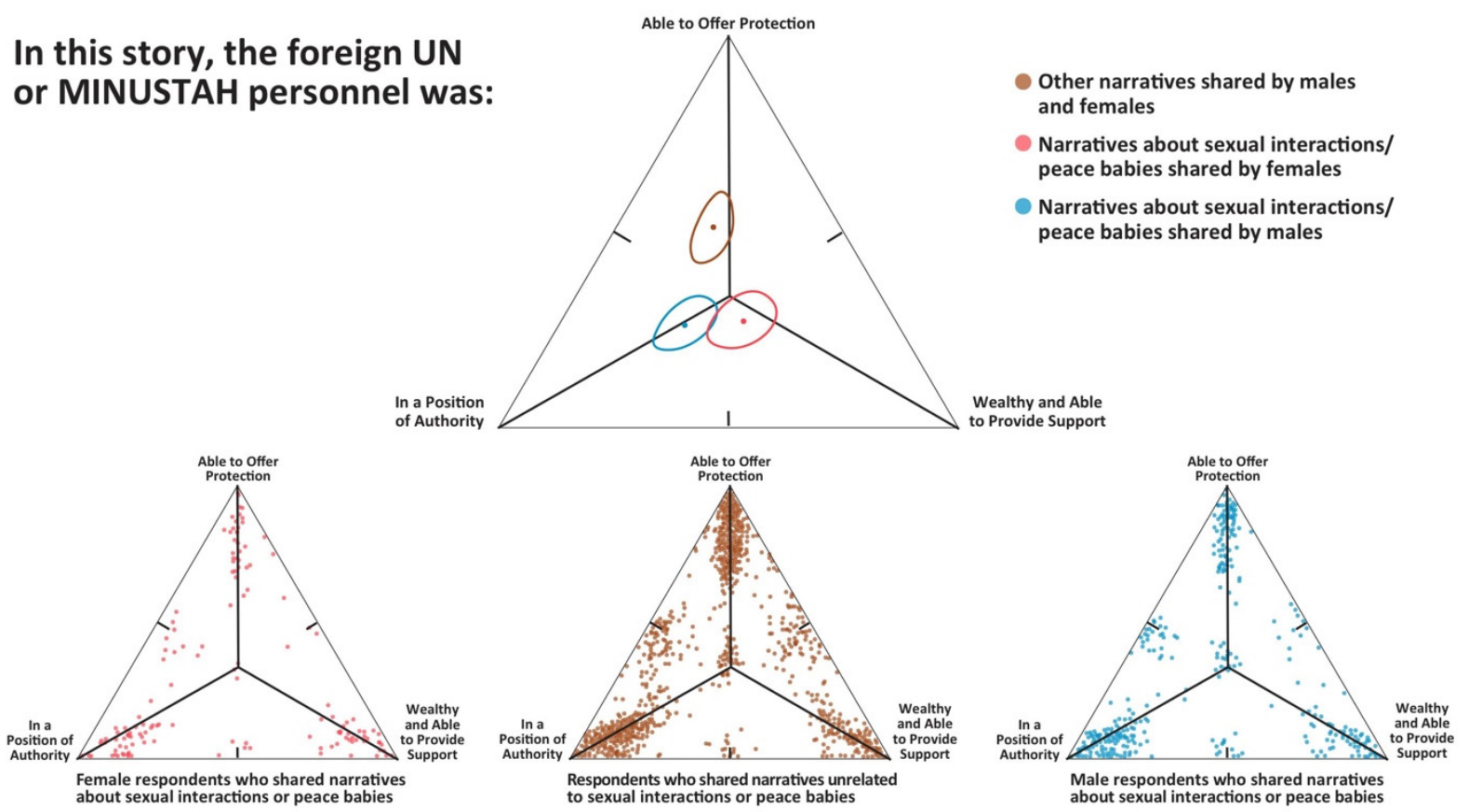

Figure 4. Disaggregated geometric means for Triad 2.

This triad illustrates that peacekeepers who perpetrate sexual misconduct are less likely to be perceived as "able to provide protection". Female Haitians who addressed sexual misconduct in their narratives may have been more likely to perceive the peacekeeper as "wealthy and able to provide support", whereas male Haitians who addressed sexual misconduct may have been more likely to perceive the peacekeeper as being "in a position of authority". Transactional sex involving Haitian children may explain the divergence of responses away from the peacekeeper being perceived as "able to provide protection". The personal connection some Haitian women have through their children fathered by peacekeepers and the subsequent economic need for peacekeepers to provide child support may explain these perceptions.

The third presented triad asked participants to consider whether the interaction in the story was (i) friendly, (ii) business, or (iii) a relationship. As illustrated in Figure 5, the geometric mean for all respondents was approximately in the middle of the triad between "friendly" and "relationship", lying closest to "business".

When the data were disaggregated, gendered perceptions relating to how Haitians classified sexual interactions involving peacekeepers were detected (Figure 6). Firstly, interactions with peacekeepers involving sexual misconduct were less likely to be about "business" compared to interactions that did not address sexual misconduct. For instance, participants who did not share narratives about sexual misconduct alluded to business interactions: informal employment opportunities with MINUSTAH peacekeepers (i.e., peacekeeping economies). One man from Morne Casse/Fort Liberté who responded in the direction of "business" stated: 


\section{Was the interaction in this story:}

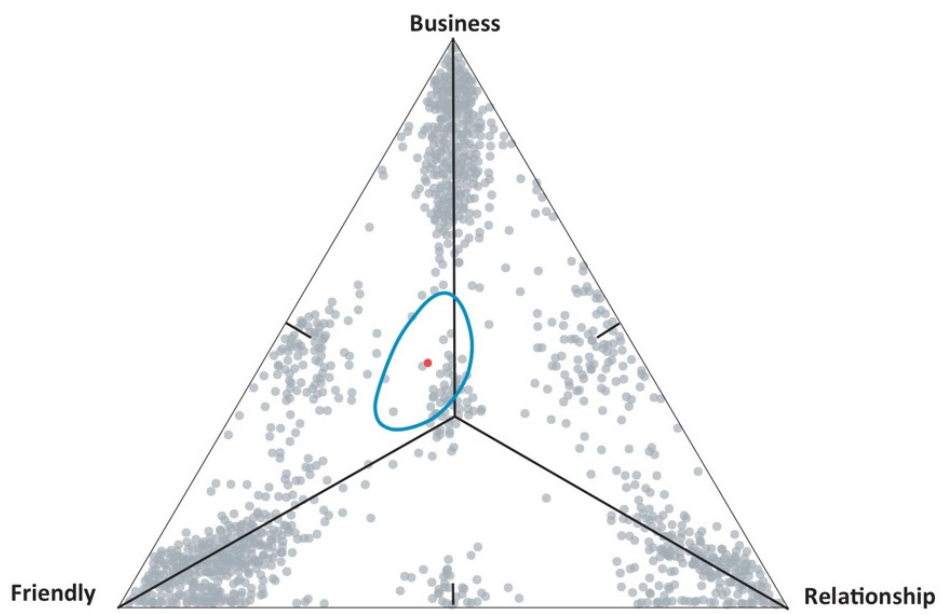

Figure 5. Aggregated geometric mean for Triad 3: Was the interaction in the story: (i) friendly, (ii) business, or (iii) a relationship.

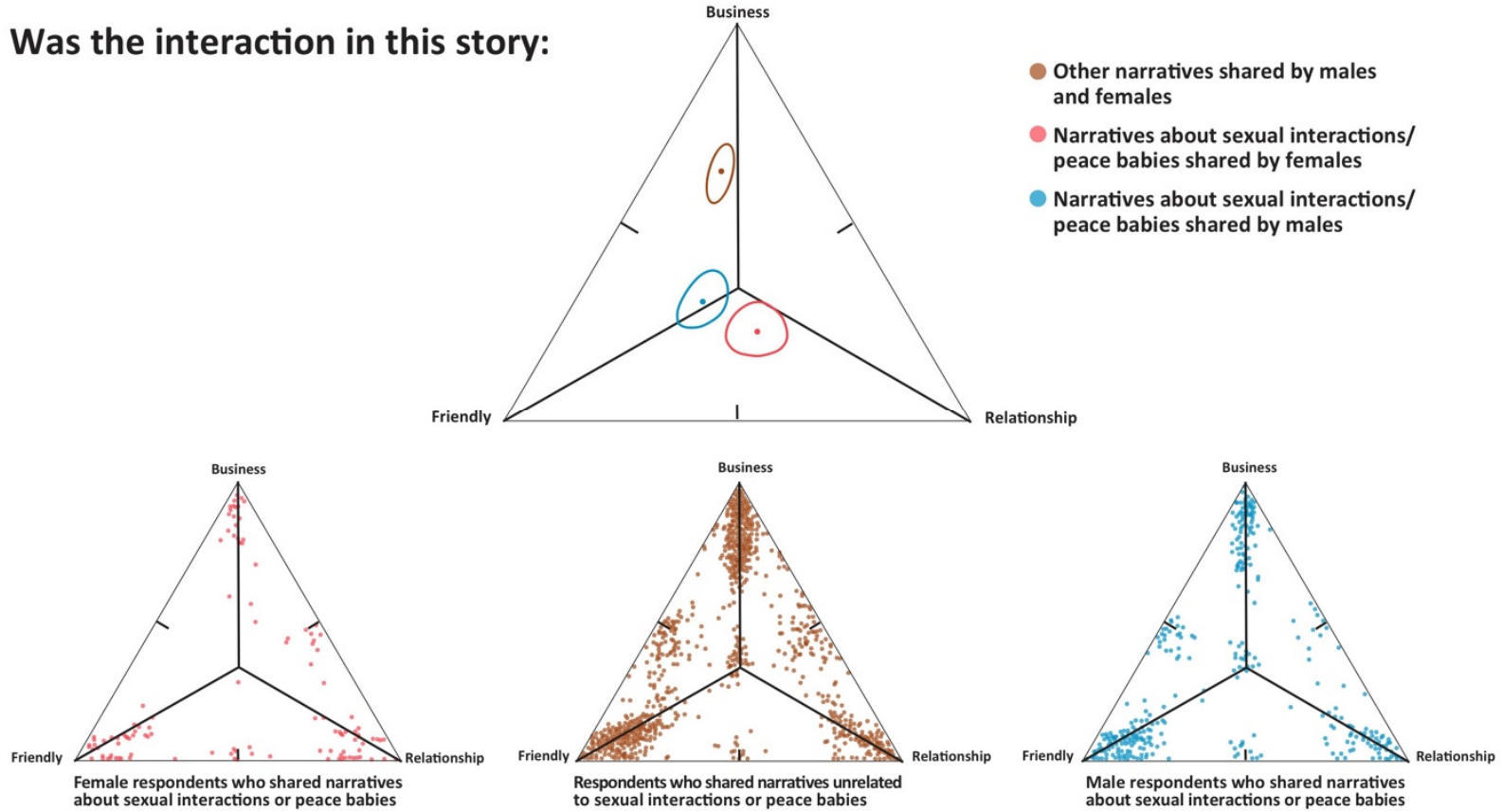

Figure 6. Disaggregated geometric means for Triad 3.

I thought that the MINUSTAH, when they came to the country, would help in developing the country, build infrastructures and schools. Although the presence of the MINUSTAH was in my profit because they hired me and I made my money with them as a carpenter, I thought they would invest more in education and other more concrete projects. If they sponsor a project for the public, they would facilitate their friends to get the project over someone else. (Morne Casse/Fort Liberté, 25-34 years old)

Haitian women who shared narratives concerning sexual interactions with peacekeepers were more likely to interpret the interaction in the direction of a "relationship" compared to Haitian men. In contrast, male respondents were more likely to perceive sexual interactions with peacekeepers as equally balanced between "business" and "friendly". For example, one Haitian woman from Port Salut described her experience dating a MINUSTAH peacekeeper: 
I met a MINUSTAH because he used to come to my house where I was selling beers. I started to talk to him, then he told me he loved me and I agreed to date him. Three months later, I was pregnant, and in September, he was sent to his country. He started sending money for the child for 2 months, but ever since, I have not heard from him. The child is growing up, and it's myself and my family that are struggling with him. I now have to send him to school. They put him out because I'm unable to pay for it. At the time, it was true I had my aunt who wanted to adopt him as her son, but I did not have the heart to do it. It took all my strength, and I agreed because I do not have any help.

(Port Salut, 25-34 years old)

Haitian men who shared narratives about sexual interactions with peacekeepers were less likely to interpret the interactions in the direction of "relationship" compared to Haitian women. Haitian men spoke frankly about the abandonment of peacekeeper-fathered children in Haiti and noted that young girls viewed the foreign peacekeepers favorably and initiated contact with them. For instance, one Haitian man from Cité Soleil stated:

The young girls, children of Cité Soleil they always like whites/foreigners. As soon as they see a foreigner, they always approach him. But it also happened that one came to have a relationship with them. They came to make [children]. Twins ... up to the present moment, they haven't taken care of them ... Also, I know a lot of children that are living with MINUSTAH children... When a foreigner that has the means in their hands, that has things they can do, that does something bad like that. That makes me say the act, because if you do it, if you get a girl pregnant, they have a child with her. But you can't take care of it, it's a dishonest act. It's a crime ... Well, today those children are growing up without fathers. But the mothers know that your father is a MINUSTAH soldier.

(Cité Soleil, 25-34 years old)

Narratives addressing sexual interactions with peacekeepers are perceived as distinct compared to narratives unrelated to sexual interactions; Haitians were less likely to perceive sexual relationships with peacekeepers as "business" interactions. "Business" relationships with peacekeepers, unrelated to sexual misconduct, illustrate that peacekeepers were a potential source of employment and income for Haitians. In contrast, Haitian women were more likely to perceive sexual interactions with peacekeepers as "relationships" compared to Haitian men. The longer-term dependency on peacekeepers and more intimate nature of sexual interactions with peacekeepers, leading to the birth of children, may explain these perceptions.

\section{Discussion}

\subsection{Summary of Findings}

SenseMaker triad questions were descriptively analyzed to identify gender differences among Haitian perceptions of civilian-peacekeeper sexual interactions. The 682 narratives about civilian-peacekeeper sexual interactions were stratified according to gender (men/boys and women/girls) and compared to narratives that were unrelated to sexual interactions. Our data did not identify gender differences between how Haitian men and women perceived the content of the narrative shared, fair responses, avenues of support, barriers to obtaining support, and the presence of the UN and MINUSTAH.

There were, however, some noteworthy differences in the perspectives of Haitian men/boys and women/girls. For instance, findings indicated that peacekeepers who perpetrated sexual misconduct were less likely to be perceived as offering protection. Haitian women/girls perceived peacekeepers involved in sexual misconduct as having the financial means to provide support, while Haitian men/boys believed that peacekeepers who perpetrated sexual misconduct were in an authoritative position. However, the gender differences noted in Figure 4 should be interpreted with caution. The $95 \%$ confidence ellipses for males and females were wide and slightly overlapped, indicating an insufficient sample size within each gender stratum to allow for the complete separation of the confidence. Therefore, to avoid a type II error, the gendered perceptions in the second triad 
were interpreted in the direction of statistical significance. Secondly, sexual interactions with peacekeepers were less likely to be perceived in terms of "business". Haitian women who shared narratives about sexual interactions with peacekeepers were more likely to interpret the interaction as being a "relationship". Alternatively, Haitian males were less likely to perceive sexual interactions with peacekeepers as "relationships".

\subsection{Contribution to Gendered Peacekeeping Discourses}

The present findings illustrate that male and female Haitians may vary in how they perceive MINUSTAH peacekeepers who engaged in sexual misconduct and how sexual interactions with peacekeepers are classified. Such novel insights advance the understanding of how gender operates vis-à-vis PKOs by considering the gender dynamics of host-country civilians. Previous scholarship around gender in PKOs has focused on the predominance of male personnel, with only $4.4 \%$ of military personnel and $11.1 \%$ of police personnel being female in 2019 [51,64]. Although men and boys also experience SEA perpetrated during PKOs $[65,66]$, SEA disproportionately affects women and girls in terms of the frequency of occurrence, the possibility of pregnancy, and the subsequent cycles of poverty [19-21].

This research illustrates that masculine and feminine social identities not only shape the composition and behavior of peacekeepers but may also influence how host-community civilians perceive peacekeepers who perpetrate SEA and how they understand the nature of SEA. During PKOs, local women and girls are positioned within a myriad of social, cultural, and economic forces that shape complex relationships with male peacekeepers [67]. Scholars have challenged the framing that all civilian-peacekeeper sexual interactions are inherently abusive and exploitative by arguing that a variety of sexual interactions occur between local women and UN peacekeepers, including sexual violence and abuse, consensual transactional sex, and long-term relationships embedded in perceptions of love $[20,26,68]$.

Similarly, the present findings support a nuanced understanding of civilian-peacekeeper sexual interactions, given that Haitian women perceive peacekeepers implicated in sexual interactions as "wealthy and able to provide support" and the sexual interactions to be "relationships". Accordingly, this gender analysis of Haitian perceptions vis-à-vis MINUSTAH critically examines the bounded agency of women and girls in contexts characterized by fragile security and pervasive poverty. Similar to other research $[20,69,70]$, our analysis also highlights how power imbalances between peacekeepers and local women and girls manifest as coercive tactics, such as the exchange of resources for sexual activity. Sexual activity as quid pro quo for receiving food, money, or other resources from peacekeepers illustrates not only the exploitative nature of SEA but also gendered understandings of transactional sex, wherein the male peacekeeper assumes the provider role [71].

In our data, women and girls did not always identify as victims of SEA while recalling the time periods in which they interacted sexually with peacekeepers. However, in the case of pregnancy, their vulnerability was sometimes later expressed in terms of being the sole caregiver for children fathered by peacekeepers. Men, on the other hand, commented on the exploitative and abusive nature of transactional sex with peacekeepers more readily than women; this was especially the case where the narrative involved SEA with children and minors.

\subsection{UN Trust Fund for Victims of SEA}

Preventing the perpetration of SEA remains the responsibility of peacekeepers, their TPCCs, and the Department of Peacekeeping Operations. As such, we acknowledge that systemic changes must occur to eliminate peacekeeper impunity, change cultures of permissibility with respect to SEA, offer comprehensive anti-SEA training to deployed peacekeepers, and improve the vetting of peacekeepers with gender inequitable attitudes $[9,72-74]$. The present micro-level analysis is directly relevant for the UN's Trust Fund in Support of Victims of Sexual Exploitation and Abuse: a harm mitigation policy approach.

Established in 2016 as part of the UN's Comprehensive Strategy on Assistance and Support of Victims of SEA by United Nations and Related Personnel, the fund secured USD 
2 million in funding for the first implementation cycle: 2017-2018 [41,75,76]. The fund's key objectives are to provide specialized services (medical, legal, psychosocial) in support of SEA victims, engage in community outreach, address service gaps in the provision of assistance and support to victims and children born from SEA, and act as additional support for affected victims $[75,76]$. The purpose of the Trust Fund is to provide victims with assistance and support rather than direct compensation.

Currently, the Trust Fund is active in the Democratic Republic of the Congo, the Central African Republic, and Liberia [75,76]. Existing programs are implemented by humanitarian organizations affiliated with the $\mathrm{UN}$ and include awareness training with community stakeholders, adult literacy programs, a two-year scholarship for children in vulnerable situations, and adult vocational training $[75,76]$. The Trust Fund's program manager, who is responsible for evaluating project grants along with the VRA and FVRAs, should consider how context-specific gender dynamics influence the manner in which host-country civilians perceive and interact with peacekeepers when assessing the efficacy and sustainability of SEA-related programs and content areas for public education and awareness building.

As our data illustrate, the exploitative nature of SEA may be obscured by gendered understandings of transactional sex and the male provider role. Accordingly, the perception in Haiti that sexual relations with peacekeepers are legitimate relationships with partners who are able to offer financial and material support may act as a barrier to women's SEAreporting behavior as well as their participation and utilization of Trust Fund programs. The Trust Fund should also consider investments in upstream interventions that target women and girls living in proximity to peacekeeping bases before sexual relations with peacekeepers begin. As such, investment in gender-transformative interventions that aim to improve the socioeconomic status of women and girls living in proximity to PKOs can proactively prevent SEA and subsequently reduce the risk of pregnancy and sexually transmitted infections and mitigate the trauma associated with sexual violence.

Our findings vis-à-vis the UN Trust Fund expand the Zeid report's acknowledgment that data on SEA cases does not reflect the true extent of such crimes and that reporting is inhibited by "cases involving prostitution, where there is no economic incentive to report" [42] (p. 10). We advocate for the UN's SEA prevention and response policies to critically consider the gendered dynamics present within the host country in order to improve trust in reporting, investigate SEA allegations, and address fundamental causes of gender inequality and host state fragility. For example, "prostitution" may not correspond to how SEA victims/survivors understand and reflect on their sexual encounters or relations with peacekeepers. A nuanced understanding of transactional sex within the context of Haitian gender roles and women and girls' socioeconomic progression is needed to better design and implement Trust Fund programs.

It is also critically important to recognize that the UN's victim-centered approach and the Trust Fund may operate on top of or in parallel to national and regional frameworks, policies, and advocacy efforts of the host country. For example, the SEA in Haiti has been experienced and perpetrated in a context where Haiti has been a signatory to the UN Convention Against all Forms of Discrimination Against Women since 1981 [77] and has created subsequent national gender equality action plans, led by the Ministry of Women and Women's Rights [78,79]. Thus, Trust Fund programs for SEA survivors in Haiti should work in partnership with existing gender equity advocacy efforts rather than displacing national actors who have invaluable contextual knowledge and experience. Creating and nurturing linkages between the UN's victim-centered approach and existing Haitian national action plans for gender equality can better address the lived experiences and needs of Haitian SEA survivors as well as state fragility.

Furthermore, by considering the perspectives of Haitian males living in proximity to MINUSTAH bases, the findings situate local Haitian men and boys as important stakeholders and key informants with respect to gender-transformative Trust Fund programs. Haitian men and boys are the brothers, fathers, friends, partners, sons, government repre- 
sentatives, and employers of women and girls who are the victims of SEA. As such, they are directly and indirectly affected by civilian-peacekeeper sexual interactions, and their perspectives are important in terms of establishing a holistic understanding of how sexual relations during PKOs affect host communities. In stratifying the perspectives of men and boys, this research also draws attention to the conflation of gender with women.

The perspectives, attitudes, and beliefs of men and boys can reinforce or challenge social norms that pertain to how women and girls interact with peacekeepers and PKO. Consequently, Trust Fund programs should also critically consider the context-specific positionality of men and boys and aim to leverage their positions to ensure successful implementation. For example, in our sample, the exploitative nature of transactional sex with peacekeepers was considered to a greater degree by Haitian men, who were commenting on SEA involving women/girls in their community, compared to the women/girls themselves. Trust Fund programs and SEA reporting mechanisms should critically examine whether the programs in place address why female victims of SEA, whether they are minors or adults, may not always identify themselves as having been exploited or abused when engaging in transactional sex with peacekeepers.

\subsection{Limitations}

This research has several limitations. Firstly, the gender imbalance noted in the sample (70\% males, $30 \%$ females) is the result of participants' self-selection out of the study. Research assistants recruited participants in naturalistic settings during the day. The recruitment sites were predominantly public spaces, including markets, post offices, and bus stops. These temporal and spatial aspects of recruitment systematically reduced the probability of recruiting certain members of the population, notably women responsible for domestic duties, childcare, persons with disabilities, and older adults. No demographic information pertaining to the non-respondents was collected. However, focus group discussions with the research assistants revealed Haitian females were more likely to self-select out of the study compared to males. Secondly, convenience sampling limits the generalizability of the results to the Haitian population. Due to prolonged political instability and earthquake-related losses such as mass death, displacement, and weak infrastructure, the 2003 Haitian census is not usable [80]. While other scholars have collected primary data using population-based samples in Haiti, they are restricted to particular areas such as metropolitan Port-au-Prince [80].

The purposeful and convenience sampling strategies employed are not ideal for generalizing results to the Haitian population at large. Nevertheless, a large sample of persons in proximity to MINUSTAH bases across rural and urban locations as well as northern, central, and southern regions was obtained, and, to our knowledge, this is the only dataset of this kind to be collected in Haiti. Compared to the 2016-2017 Demographic and Health Survey (DHS) in Haiti, a greater proportion of participants in the sample reported achieving higher levels of education and income, were male, and were single/never married. Therefore, the sample obtained for the cross-sectional survey was not an accurate representation of the Haitian population at large, based on the 2016-2017 DHS data, but may be more reflective of Haitians present in public spaces that were in proximity to MINUSTAH bases in 2017. Lastly, given the incomplete separation of confidence ellipses, the sample of men and women obtained may have been underpowered.

\subsection{Strengths}

The present study has notable strengths. To our knowledge, this is the first empirical study highlighting gendered perceptions of peacekeepers who perpetrate SEA from the perspectives of host-country civilians. Additionally, the use of SenseMaker as a data collection and analysis tool allowed experiences related to SEA to emerge from the participants' everyday interactions with MINUSTAH. While other SenseMaker studies pertaining to gender-based violence exist $[58,81,82]$, the present analysis is the first attempt to understand gendered differences using micro-level data collected using SenseMaker. Lastly, the mixed- 
methods analysis supports a holistic understanding of micro-level gender differences in how Haitians perceive peacekeepers who perpetrate SEA.

\section{Conclusions}

This research sought to explore gender differences among community-level perceptions of SEA perpetrated by UN peacekeepers in Haiti. Using a novel data collection tool that enabled the collection of participants' self-coded attitudes and beliefs, micro-level data pertaining to Haitian perceptions of MINUSTAH were disaggregated by gender. Our findings indicate that while no gender differences were detected regarding legitimate forms of justice and support following the occurrence of SEA, Haitian men/boys and women/girls differed in how they perceived peacekeepers who perpetrated SEA and how to classify SEA interactions. Compared to Haitian men/boys, Haitian women/girls perceived SEA interactions as relationships with wealthy partners who were able to provide support.

Author Contributions: Conceptualization L.V., H.S. and S.A.B.; methodology, L.V., H.S. and S.A.B.; formal analysis, L.V., H.S. and S.A.B.; investigation, L.V., H.S., S.A.B., S.E. and S.L.; resources, S.A.B. and S.L.; data curation, S.A.B., S.L. and S.E.; writing-original draft preparation, L.V.; writingreview and editing, L.V., H.S., S.A.B., S.E. and S.L.; visualization, L.V. and S.A.B.; supervision, S.A.B., S.L. and H.S.; project administration, S.A.B. and S.E.; funding acquisition, S.A.B., S.L. and L.V. All authors have read and agreed to the published version of the manuscript.

Funding: Funding was provided by the UK Arts and Humanities Research Council (AH/P008038/1) and The Social Sciences and Humanities Research Council of Canada (Partnership Development Grant \#890-2016-0110, Canada Graduate Scholarship-Masters). The funders did not contribute to the study design, implementation, or analysis.

Institutional Review Board Statement: The study was conducted according to the guidelines of the Declaration of Helsinki. The University of Birmingham's Ethical Review Board (protocol ERN_160950) and Queen's University Health Sciences and Affiliated Teaching Hospitals Research Ethics Board (\#6020398; \#6023714) granted research ethics approval for the cross-sectional survey and the secondary analysis.

Informed Consent Statement: Participants indicated their willingness to participate by tapping a consent box on the tablet after reviewing consent forms and information in Kreole and having an opportunity to ask clarifying questions. Written consent was waived, given the study was deemed to involve minimal risk. The survey was implemented privately, and no information that could identify participants was collected.

Data Availability Statement: The datasets supporting the conclusions of this article are available in Figshare (https:/ / figshare.com/s/896ed7d25a1fa1a4a09b). Accessed date (3 April 2020).

Acknowledgments: Our community partners from Komisyon Fanm Viktim pou Viktim (KOFAVIV), the former Enstiti Travay Sosyal ak Syans Sosyal (ETS), and Bureau des Avocates Internationaux (BAI) were instrumental in implementing this research and conceptualizing the study design. We recognize their contextual expertise in shaping this study and interpreting the findings, in particular, the Haitian research assistants who collected the data and participated in focus group discussions to interpret the present findings. The authors would also like to thank Laurie Webster (QED Insight consultant) for her statistical analysis support. We also acknowledge the Haitians who participated in this study by sharing their lived experiences vis-à-vis peacekeeping bases. Lastly, we are indebted to the UK Arts and Humanities Research Council and the Social Sciences and Humanities Research Council of Canada for their financial support.

Conflicts of Interest: The authors declare no conflict of interest.

\section{Appendix A. SenseMaker ${ }^{\circledR C}$ ross-Sectional Survey Prompting Questions:}

1. Describe the best or worst experience of a particular woman or girl in your community who has interacted with foreign UN or MINUSTAH personnel. What happened? 
2. Describe how living in a community with a UN or MINUSTAH presence has provided either a particular opportunity or a danger to a particular woman or girl in the community. What happened?

3. Describe the negative or positive experience of a particular women or girl who requested support or assistance after interacting with foreign UN or MINUSTAH personnel. What happened?

\section{Triad Questions:}

To answer the question, use your finger to drag the ball in each triangle to a position that best describes the experience shared in the story. The closer the ball to any one corner, the stronger that quality is in the context of the experience. If a triangle topic does not relate to your experience or you prefer to not answer the question, check the Not Applicable box by pressing on it with your finger.

1. This story is about: 1. Financial/material security, 2. Social status, 3. Emotional needs.

2. In this story, the foreign UN or MINUSTAH personnel was: 1 . In a position of authority, 2. Able to offer protection, 3. Wealthy and able to provide support.

3. Was the interaction in the story: 1. Friendly, 2. Business, 3. Relationship.

4. In the story, what would a fair response look like? 1. Acceptance of responsibility, 2. Justice, 3. Reparation.

5. In the story, it would have helped the woman or girl most to have had support from: 1 . The UN or MINUSTAH, 2. NGOs or civil society organizations, 3. Haitian authorities.

6. In the story, barriers to the woman or girl getting a fair response were: 1 . Lack of information in the community about assistance, 2. Lack of response from Haitian authorities, 3. Lack of response from the UN or MINUSTAH.

7. In the story, what would have helped most to make the experience more positive: 1. Material/financial support, 2. Emotional support, 3. Legal support.

8. Based on the events in the story, the presence of the UN or MINUSTAH led to: 1. Disrespect of Haitian values and laws, 2. Negative financial impact, 3. Anger and resentment.

\section{Multiple Choice Questions Pertaining to the Narrative:}

(M1) Who is the story about?

- About me

- About someone in my household

- About someone in my family who doesn't live in my household

- About a friend

- Community

- Something I heard or read about

- Prefer not to say

(M2) How often does the situation in this story occur?

- Very rarely

- Occasionally

- Regularly

- Very frequently

- All the time

- Not sure

(M3) How important is it for others to hear and learn from your story

- Must hear this story and take action

- Should definitely hear this story and pay attention

- Can learn something

(M4) Who would most benefit from hearing the story shared? (choose up to three)

- Family

- Friends 
- Neighbors

- Haitian politicians

- $\quad$ The UN or MINUSTAH

- NGOs

- The military of the foreigner

- Churches

- Community leaders

- Business people

- Girls in my community

- Women in my community

- Men in my community

- Not sure

(M5) What is the emotional tone of this story?

- Strongly positive

- Positive

- Neutral

- Negative

- Very negative

- Not sure

(M6) How does your story make you feel (choose up to 3):

- Angry

- Disappointed

- Embarrassed

- Encouraged

- Frustrated

- Good

- Happy

- Hopeful

- Indifferent

- Relieved

- Sad

- Satisfied

- Worried

- Not sure

(M7) What country was the foreigner in the story from?

- Uruguay

- Sri Lanka

- Pakistan

- Nepal

- Argentina

- Bolivia

- Brazil

- Chile

- Peru

- Indonesia

- Jordan

- Nigeria

- Pakistan

- Indonesia

- Senegal

- United States

- France

- Canada 
- Japan

- China

- Other

- Don't know

(M8) What was the role of the foreigner with the UN or MINUSTAH?

- Soldier (UNPOL, MINUSTAH, or Multinational Forces)

- Civilian who works with the UN (doesn't wear a uniform)

- Police

- Worked for an NGO rather than the UN or MINUSTAH

- Other

- Don't know

Multiple Choice Questions Pertaining to the Participant:

(D1) What is your gender?

- Female

- Male

- Prefer not to say

(D2) How old are you:

- 11-17 years old

- 18-24 years old

- 25-34 years old

- 35-44 years old

- 45-54 years old

- $\quad \geq 55$ years old

(D3) What is your marital status?

- Married or living together as if married

- Divorced/Separated from spouse

- Widowed

- Single, never married

- Prefer not to say

(D4) What is your highest educational qualification?

- No formal education

- Some primary school

- Completed primary school

- Some secondary school

- Completed secondary school

- Some post-secondary school

- Completed post-secondary school

(D5) I'll read you a list of 5 items that some people have at home. Please tell me which of these you or your household owns. Your household consists of people who sleep under the same roof and eat the same meals. Chose as many as your family has:

- radio

- mobile phone

- refrigerator or freezer

- vehicle such as a truck, a car or a motorcycle

- generator, inverter, or sun panel that provides electricity to your home.

- None of the above

(D6) Here are some questions about your life

- 7 Strongly agree

- 6 Agree

- 5 Slightly agree

- 4 Neither agree nor disagree 
- 3 Slightly disagree

- 2 Disagree

- 1 Strongly disagree In most ways, my life is close to my ideal. The conditions of my life are excellent. I am satisfied with my life. So far, I have gotten the important things I want in life. If I could live my life over, I would change almost nothing.

Multiple Choice Questions for the Research Assistant (not presented or answered by the participants)

(I1) Which category/group does this narrator belong?

- Child fathered by foreign UN or MINUSTAH personnel

- Woman or girl who had interacted with foreign UN or MINUSTAH personnel

- Family member of a woman or girl who had interacted with foreign UN or MINUSTAH personnel

- Friend of a woman or girl who had interacted with foreign UN or MINUSTAH personnel

- Community member where foreign UN or MINUSTAH personnel are hosted

- Community leader where foreign UN or MINUSTAH personnel are hosted

- Foreign UN or MINUSTAH personnel

- Haitian UN or MINUSTAH personnel

- Politician

- NGO staff

- Other

(I2) In what location was the interview conducted?

- Cité Soleil

- Charlie Log Base/Tabarre

- Gonaives

- St. Marc

- Hinche

- Leogane

- Port Salut

- Miragoane

- Morne Casse/Fort Liberté

- Cap Haitien

(I3) Do you think the participant was comfortable taking part in this survey? (choose up to three)

- No-because of the survey

- No-because of the topic

- No-because of the iPad

- No-because of the voice recording

- No-because of the SenseMaker questions

- No-because of concerns about motivations or identity of the researchers

- No-because of voodoo-related fears or concerns

- No-other

- Yes

- Not sure

(I4) Was this story about a peace baby?

- About a peace baby

- Mentioned a peace baby

- About sexual abuse or exploitation by UN or MINUSTAH but not a peace baby

- No 
- Not sure

(I5) Was this story about cholera?

- About cholera

- Mentioned cholera

- About wrongdoings committed by foreign UN or MINUSTAH personnel but not about cholera

- No

- Not sure

(I6) Would you flag this story for translation and further analysis based on richness or interest?

- Yes

- No

- Not sure

(I7) Which story number is this for this participant?

- 1 st

- 2nd

- $3 r d$

- 4 th

\section{References}

1. Jennings, K. The Immunity Dilemma: Peacekeepers' Crimes and the UN's Response. Available online: http://www.e-ir.info/20 17/09/18/the-immunity-dilemma-peacekeepers-crimes-and-the-uns-response/ (accessed on 14 October 2020).

2. Hultman, L.; Kathman, J.D.; Shannon, M. Peacekeeping in the Midst of War; Oxford University Press: Oxford, UK, 2019. [CrossRef]

3. Grewal, B.S. Johan Galtung: Positive and Negative Peace; Auckland University of Technology: Aukland, Australia, 2003.

4. Hatto, R. From peacekeeping to peacebuilding: The evolution of the role of the United Nations in peace operations. Int. Rev. Red Cross 2014, 95, 495-515. [CrossRef]

5. Willmot, H.; Sheeran, S. The protection of civilians mandate in un peacekeeping operations: Reconciling protection concepts and practices. Int. Rev. Red Cross 2014, 95, 517-538. [CrossRef]

6. Heine, J.; Thompson, A. Introduction: Haiti's governance challenges and the international community. In Fixing Haiti: MINUSTAH and Beyond; Heine, J., Thompson, A., Eds.; United Nations University Press: New York, NY, USA, 2011; pp. 1-21.

7. United Nations MINUSTAH: United Nations Peacekeeping. Available online: https://peacekeeping.un.org/en/mission/ minustah (accessed on 4 February 2020).

8. United Nations Peacekeeping United Nations Stabilization Mission in Haiti (MINUSTAH). Available online: https: //peacekeeping.un.org/en/mission/minustah (accessed on 3 April 2020).

9. Connors, J. A victims' rights approach to the prevention of, and response to, sexual exploitation and abuse by United Nations personnel. Aust. J. Hum. Rights 2019, 25, 498-510. [CrossRef]

10. United Nations Conduct in UN Peace Missions: Sexual Exploitation and Abuse. Available online: https:/ / conduct.unmissions. org/sea-overview (accessed on 21 March 2020).

11. Beber, B.; Gilligan, M.J.; Guardado, J.; Karim, S. Peacekeeping, compliance with international norms, and transactional sex in Monrovia, Liberia. Int. Organ. 2017, 71, 1-30. [CrossRef]

12. Neudorfer, K. Sexual Exploitation and Abuse in UN Peacekeeping: An Analysis of Risk and Prevention Factors; Lexington Books: London, UK, 2015; ISBN 978-0-7391-9961-9.

13. Nordås, R.; Rustad, S.C.A. Sexual exploitation and abuse by peacekeepers: Understanding variation. Int. Interact. 2013, 39, 511-534. [CrossRef]

14. Al Jazeera Uruguay Apologises over Alleged Rape in Haiti I Environment News | Al Jazeera. Available online: https:/ / www. aljazeera.com/news/2011/9/7/uruguay-apologises-over-alleged-rape-in-haiti (accessed on 6 April 2021).

15. A Scandal of Sexual Abuse Mars the UN's Exit from Haiti 2017. The Washington Post. Available online: https://www. washingtonpost.com/opinions/a-scandal-of-sexual-abuse-mars-the-uns-exit-from-haiti/2017/04/16/d6947bde-213a-11e7 -ad74-3a742a6e93a7_story.html (accessed on 16 April 2017).

16. Williams, C.J. UN Confronts Another Sex Scandal-Los Angeles Times. Available online: https://www.latimes.com/archives/laxpm-2007-dec-15-fg-haitisex15-story.html (accessed on 6 April 2021).

17. United Nations Secretariat. Special Measures for Protection from Sexual Exploitation and Sexual Abuse; United Nations: Geneva, Switzerland, 2003.

18. Jennings, K.M. Protecting Whom? Approaches to Sexual Axploitation and Abuse UN Peacekeeping Operations; Norwegian Ministry of Foreign Affairs: Oslo, Norway, 2008. 
19. Vahedi, L.; Bartels, S.; Lee, S. "His Future will not be Bright": A qualitative analysis of mothers' lived experiences raising peacekeeper-fathered children in Haiti. Child. Youth Serv. Rev. 2020, 119, 105625. [CrossRef]

20. Vahedi, L.; Bartels, S.A.; Lee, S. 'Even peacekeepers expect something in return': A qualitative analysis of sexual interactions between UN peacekeepers and female Haitians. Glob. Public Health 2019, 1692, 1-14. [CrossRef]

21. Lee, S.; Bartels, S. 'They Put a Few Coins in Your Hand to Drop a Baby in You': A Study of Peacekeeper-fathered Children in Haiti. Int. Peacekeeping 2020, 27, 177-209. [CrossRef]

22. Kanetake, M. Whose zero tolerance counts? Reassessing a zero tolerance policy against sexual exploitation and abuse by UN peacekeepers. Int. Peacekeeping 2010, 17, 200-214. [CrossRef]

23. McGill, J. Survival sex in peacekeeping economies: Re-reading the zero tolerance approach to sexual exploitation and sexual abuse in United Nations peace support operations. J. Int. Peacekeeping 2014, 18, 1-44. [CrossRef]

24. Otto, D. Making sense of zero tolerance policies in peacekeeping sexual economies. In Sexuality and the Law: Feminist Engagements; Munro, V., Stychin, C.F., Eds.; GlassHouse Press: London, UK, 2007; pp. 259-282. ISBN 9780203945094.

25. Simi, B.O.; United Nations; Westendorf, J.-K.; Searle, L.; Spangaro, J.; Adogu, C.; Ranmuthugala, G.; Powell Davies, G.; Steinacker, L.; Zwi, A.; et al. Sexual exploitation and abuse by UN peacekeepers: A threat to impartiality. Int. Peacekeeping 2017, 17, 1-13. [CrossRef]

26. Simić, O.; O’Brien, M. "Peacekeeper babies": An unintended legacy of United Nations peace support operations. Int. Peacekeeping 2014, 21, 345-363. [CrossRef]

27. Faedi, B. The double weakness of girls: Discrimination and sexual violence in Haiti. Stanford J. Int. Law 2008, 44, 147-204.

28. Dupuy, A. Haiti: From Revolutionary Slaves to Powerless Citizens: Essays on the Politics and Economics of Underdevelopment; Routeledge: London, UK, 2014.

29. Diehl, P.F. Peace Operations (War and Conflict in the Modern World), 1st ed.; Polity Press: Cambridge, UK, 2008.

30. Clark, M. Domestic violence in the Haitian culture and the American legal response: Fanm ahysyen ki gen kouraj. Univ. Miami Inter Am. Law Rev. 2006, 37, 297-317.

31. Immigration and Refugee Board of Canada Haiti: Violence against Women, Including Sexual Violence; State Protection and Support Services (2012-June 2016). Available online: https:/ / www.refworld.org/docid/58d539d04.html (accessed on 7 March 2021).

32. Reiz, N.; O'Lear, S. Spaces of Violence and (In)justice in Haiti: A Critical Legal Geography Perspective on Rape, UN Peacekeeping, and the United Nations Status of Forces Agreement. Territ. Polit. Gov. 2016, 4, 453-471. [CrossRef]

33. Fox, C. Violent sex: How gender-based violence is structured in Haiti, healthcare \& HIV/AIDS. Indiana J. Law Soc. Enq. 2013, 2, 202-229.

34. Kolbe, A.R. 'It's Not a Gift When It Comes with a Price': A Qualitative Study of Transactional Sex between UN Peacekeepers and Haitian Citizens. Stab. Int. J. Secur. Dev. 2015, 4, 1-26. [CrossRef]

35. Daniel, C.A.; Logie, C. Transactional Sex among Young Women in Post-Earthquake Haiti: Prevalence and Vulnerability to HIV. J. Sociol. Soc. Work 2017, 5, 54-67. [CrossRef]

36. United Nations. Charter of the United Nations and Statute of the Charter of the International Court of Justice; United Nations: New York, NY, USA, 1945; Volume 55, ISBN 9789210020251.

37. Simm, G. Sex in Peace Operations; Oxford Universiry Press: Oxford, UK, 2013.

38. Blau, L. Victimizing those they were sent to protect: Enhancing accountability for children born of sexual abuse and exploitation by UN peacekeepers. Syracuse J. Int. Law Commer. 2016, 44, 122-148. [CrossRef]

39. Ndulo, M. The United Nations Responses to the Sexual Abuse and Exploitation of Women and Girls by Peacekeepers during Peacekeeping Missions Peacekeeping Missions. Berkeley J. Int'l Law 2009, 27, 127.

40. Rehn, E.; Sirleaf, E. Women, War and Peace: The Independent Experts' Assessment on the Impact of Armed Conflict on Women and Women's Role in Peace-Building; UN Women: New York, NY, USA, 2002.

41. United Nations. Resolution 62/214: United Nations Comprehensive Stragety on Assistance and Support to Victims of Sexual Exploitation and Abuse by United Nations Staff and Related Personnel; United Nations: New York, NY, USA, 2008.

42. United Nations Secretariat. A Comprehensive Strategy to Eliminate Future Exploitation and Abuse in United Nations Peacekeping Operations; United Nations: New York, NY, USA, 2005; Volume 24790.

43. Notar, S.A. Peacekeepers as perpetrators: Sexual exploitation and abuse of women and children in the Democratic Republic of the Congo. J. Gender Soc. Policy Law 2006, 14, 413-429.

44. United Nations Secretary General. Special Measures for Protection from Sexual Exploutation and Abuse; United Nations: New York, NY, USA, 2020.

45. United Nations. Peacekeeping Disciplinary Processes / Conduct in UN Field Missions. Available online: https://conduct. unmissions.org/enforcement-disciplinary (accessed on 1 April 2020).

46. United Nations Secretary General. Special Measures for Protection from Sexual Exploitation and Abuse: A New Approach Report; United Nations: New York, NY, USA, 2017.

47. Cislaghi, B.; Heise, L. Gender norms and social norms: Differences, similarities and why they matter for effective global health action. Sociol. Health Illn. 2019, 42, 407-422. [CrossRef] [PubMed]

48. United Nations. Women Women, Peace and Security / UN Women-Headquarters. Available online: https://www.unwomen. org/en/news/in-focus/women-peace-security (accessed on 18 March 2020). 
49. United Nations. United Nations Security Council Resolution 1325 (2000) on Women, Peace and Security: Understanding the Implications, Fulfilling the Obligations; United Nations: New York, NY, USA, 2000; Volume 1325, ISBN 1212963180.

50. Henry, M.G. Keeping the peace: Gender, geopolitics and global governance interventions. Confl. Secur. Dev. 2019, 19, 263-268. [CrossRef]

51. Higate, P. Peacekeepers, masculinities, and sexual exploitation. Men Masc. 2007, 10, 99-119. [CrossRef]

52. Bleckner, J. From Rhetoric to reality: A pragmatic analysis of the integration of women into un peacekeeping operations. J. Int. Peacekeeping 2013, 17, 337-360. [CrossRef]

53. Karim, S. Reevaluating peacekeeping effectiveness: Does gender neutrality inhibit progress? Int. Interact. 2017, $43,822-847$. [CrossRef]

54. Karim, S.; Beardsley, K. Female peacekeepers and gender balancing: Token gestures or informed policymaking? Int. Interact. 2013, 39, 461-488. [CrossRef]

55. Jennings, K.M.; Nikolić-Ristanović, V. UN Peacekeeping Economies and Local Sex Industries: Connections and Implications; MICROCON: Brighton, UK, 2009.

56. Cognitive Edge about Us: Cognitive Edge. Available online: http:/ / cognitive-edge.com/about-us / (accessed on 21 June 2018 ).

57. Girl Hub. Using Sensemaker®to Understand Girls' Lives: Lessons Learnt; Girls not Brides: London, UK, 2014.

58. Bartels, S.A.; Michael, S.; Roupetz, S.; Garbern, S.; Kilzar, L.; Bergquist, H.; Bakhache, N.; Davison, C.; Bunting, A. Making sense of child, early and forced marriage among Syrian refugee girls: A mixed methods study in Lebanon. BMJ Glob. Health 2018, 3, e000509. [CrossRef]

59. Fleming, P.J.; Wallace, J.J. How not to lie with statistics: The correct way to summarize benchmark results. Commun. ACM 2002, 29, 218-221. [CrossRef]

60. Webster, S. Statistics in the Triad, Part I: Geometric Mean. Available online: http:/ / qedinsight.com/2016/03/28/geometric-mean/ (accessed on 11 March 2019).

61. Csaky, C. No One to Turn To No One to Turn To; Save the Children: London, UK, 2008.

62. Diaz Perez, A.; Vega Ochoa, A.D.; Oñate, Z.R. The Informed Consent/Assent from the Doctrine of the Mature Minor. Glob. J. Health Sci. 2018, 10, 124. [CrossRef]

63. Weir, K. Studying Adolescents without Parents' Consent: A New APA Resolution Supports Mature Minors' Participation in Research without Parental Permission. Available online: https://www.apa.org/monitor/2019/02/parents-consent (accessed on 3 April 2020).

64. United Nations Peacekeeping Women in Peacekeeping / United Nations Peacekeeping. Available online: https://peacekeeping. un.org/en/women-peacekeeping (accessed on 18 March 2020).

65. Linos, N. Rethinking gender-based violence during war: Is violence against civilian men a problem worth addressing? Soc. Sci. Med. 2009, 68, 1548-1551. [CrossRef]

66. Touquet, H.; Gorris, E. Out of the shadows? The inclusion of men and boys in conceptualisations of wartime sexual violence. Reprod. Health Matters 2016, 24, 36-46. [CrossRef]

67. Higate, P.; Henry, M. Engendering (in)security in peace support operations. Secur. Dialogue 2004, 35, 461-478. [CrossRef]

68. Simić, O. Rethinking "sexual exploitation" in UN peacekeeping operations. Womens. Stud. Int. Forum 2009, 32, 288-295. [CrossRef]

69. Jennings, K.M.; Bøås, M. Transactions and interactions: Everyday life in the peacekeeping economy. J. Interv. Statebuild. 2015, 9, 281-295. [CrossRef]

70. Mudgway, C. Sexual exploitation by UN peacekeepers: The 'survival sex' gap in international human rights law. Int. J. Hum. Rights 2017, 21, 1453-1476. [CrossRef]

71. Stoebenau, K.; Heise, L.; Wamoyi, J.; Bobrova, N. Revisiting the understanding of "transactional sex" in sub-Saharan Africa: A review and synthesis of the literature. Soc. Sci. Med. 2016, 168, 186-197. [CrossRef]

72. Defeis, E.F. U.N. Peacekeepers and Sexual Abuse and Exploitation: An End to Impunity. Washingt. Univ. Glob. Stud. Law Rev. 2008, 7, 185-214. [CrossRef]

73. Freedman, R. UN immunity or impunity? A human rights based challenge. Eur. J. Int. Law 2014. [CrossRef]

74. Freedman, R. UNaccountable: A New Approach to Peacekeepers and Sexual Abuse. Eur. J. Int. Law 2018. [CrossRef]

75. United Nations. 2017 and 2018 Report: Trust Fund in Support of Victims of Sexual Exploitation and Abuse; United Nations: New York, NY, USA, 2019.

76. United Nations. 2019 Update: Trust Fund in Support of Victims of Sexual Exploitation and Abuse; United Nations: New York, NY, USA, 2019.

77. United Nations. United Nations Treaty Collection. Available online: https://treaties.un.org/pages/ViewDetails.aspx?src= TREATY\&mtdsg_no=IV-8\&chapter=4\&clang=_en (accessed on 18 April 2021).

78. République d'Haïti. Plan National 2017-2027 de Lutte Contre les Violences Envers les Femmes; République d'Haïti: Port-au-Prince, Haiti, 2017.

79. Ministère de la Santé Publique. Politique Nationale de Recherche en Santé Publique et de la Population; Ministère de la Santé Publique: Port-au-Prince, Haiti, 2020.

80. Gordon, G.M.; Young, L.E. Cooperation, information, and keeping the peace: Civilian engagement with peacekeepers in Haiti. J. Peace Res. 2017, 54, 64-79. [CrossRef] 
81. Bakhache, N.; Michael, S.; Roupetz, S.; Garbern, S.; Bergquist, H.; Davison, C.; Bartels, S. Implementation of a SenseMaker®research project among Syrian refugees in Lebanon. Glob. Health Action 2017, 10, 1362792. [CrossRef] [PubMed]

82. Bartels, S.A.; Michael, S.; Vahedi, L.; Collier, A.; Kelly, J.; Davison, C.; Scott, J.; Parmar, P.; Geara, P. SenseMaker®as a Monitoring and Evaluation Tool to Provide New Insights on Gender- Based Violence Programs and Services in Lebanon. Eval. Program Plann. 2019, 77, 101715. [CrossRef] [PubMed] 